\title{
PEMANFAATAN LIMBAH SERABUT (FIBER) KELAPA SAWIT DALAM PEMBUATAN POT ORGANIK
}

\author{
Jaka Darma Jaya, Adzani Ghani Ilmannafian, Maimunah \\ Jurusan Teknologi Industri Pertanian, Politeknik Negeri Tanah Laut \\ J1. A. Yani, Km.6, Desa Panggung, Pelaihari, Kalimantan Selatan 70815, Indonesia \\ Email: jaka_dj@politala.ac.id
}

\begin{abstract}
Plastic pots are widely used in agriculture and forestry nurseries. Its popular use has resulted in the increased pollution to the environment because they can not be decomposed by soil microorganism. It is therefore necessary to find an alternative substitute for pots made from an organic material. This study was aimed to optimize the composition of the addition of natural adhesives in the manufacture of organic pots made from fiber as palm oil waste. Furthermore, this research was conducted to characterize the physical and level of acceptance of organic pots. This study used an experimental method where results are concluded from the water content, water absorption, hedonic test and hedonic quality test. The organic pot moisture content was between 10.11-10.59\%, while the absorption of organic pot water was between 129.25$155.48 \%$. Pot with the lowest moisture content and water absorption was obtained from P2 treatment. The result of hedonic test shown that the highest level of pot acceptance in terms of color was the pot of treatment P5 and the texture aspect was the pot of treatment P1.
\end{abstract}

Keywords: fiber, gambier, organic pots, tapioca

\begin{abstract}
Abstrak
Pot plastik sangat banyak digunakan dalam persemaian tanaman pertanian, perkebunan, dan kehutanan. Penggunaan yang semakin banyak berpotensi mencemari lingkungan karena limbah plastik tidak dapat terurai oleh mikroba tanah. Oleh karena itu diperlukan alternatif pengganti pot yang terbuat dari bahan organik. Penelitian ini bertujuan untuk melakukan optimasi komposisi penambahan perekat alami pada pembuatan pot organik berbahan baku limbah serabut (fiber) kelapa sawit, serta melakukan mengkarakterisasi fisik dan tingkat kesukaan terhadap pot organik. Penelitian ini menggunakan metode eksperimental yang hasilnya di uji hedonik, mutu hedonik, kadar air, dan daya serap air. Hasil penelitian menunjukkan, kadar air pot organik berkisar antara 10,11-10,59\%. Sedangkan daya serap air pot organik berkisar antara 129,25-155,48\%. Pot dengan kadar air dan daya serap air paling rendah diperoleh dari perlakuan P2. Uji hedonik pot organik menunjukkan bahwa tingkat penerimaan pot tertinggi dari segi warna adalah pot dari perlakuan P5 dan segi tekstur adalah pot dari perlakuan P1.
\end{abstract}

Kata kunci: fiber, gambir, tapioka, pot organik

\section{PENDAHULUAN}

Sampah plastik merupakan permasalahan global lingkungan yang jumlah dan jenisnya berbedabeda di setiap negara (Verma et al., 2016). Salah satu sumber cemaran plastik adalah pot plastik dengan durabilitas rendah yang banyak digunakan untuk persemaian mulai dari tanaman pertanian, 
perkebunan hingga tanaman perhutanan. Sampah dari pot plastik tersebut sangat sukar terurai oleh mikroba di dalam tanah, sehingga dapat mencemari lingkungan (Alshehrei, 2017).

Salah satu cara untuk mengatasi kelemahan dari penggunaan pot plastik adalah dengan memberikan alternatif pengganti pot yang ramah lingkungan yaitu wadah semai berbahan dasar organik. Bahan organik seperti pati, gambir dan sejenisnya sudah mulai dikembangkan sebagai bahan baku dan perekat dalam pembuatan plastic yang mudah terdegradasi (Kamsiati et al., 2017; Kasim, et al., 2018). Bahan organik lain yang berpotensi besar untuk digunakan sebagai bahan pembuatan pot organik yang dapat terdegradasi adalah limbah serabut (fiber) kelapa sawit, dikarenakan jumlahnya yang sangat besar mencapai 13\% dari total berat tandan buah segar (TBS) kelapa sawit (Susilawati dan Supijatno, 2015).

Selain mudah terdegradasi dan tidak mencemari lingkungan, pot organik juga dapat langsung ditanam di dalam tanah dan menambah bahan organik pada tanah. Pot organik dapat menjadi salah satu media tanam yang memiliki kandungan hara yang cukup baik, sehingga memberikan sumbangsih terhadap kelestarian tanah dan lingkungan. Berdasarkan hal tersebut pot organik diharapkan mampu menunjang pertumbuhan tanaman dan menjadi wadah semai dan tanam alternatif yang ramah lingkungan (Nursyamsi, 2015). Penelitian ini bertujuan untuk melakukan optimasi pembuatan pot organik berbahan baku limbah fiber kelapa sawit dengan variasi penambahan perekat alami yaitu kanji dan gambir.

\section{METODE PENELITIAN}

\subsection{Pembuatan Pot Organik}

Serabut (fiber) kelapa sawit yang sudah dipotong kecil-kecil $( \pm 0,5 \mathrm{~cm})$ disiapkan sebanyak 100 gram. Kemudian ditimbang perekat kanji dan gambir sesuai dengan komposisi yang telah ditentukan (Tabel 1). Variasi komposisi kanji dan gambir pada penelitian ini bertujuan untuk mendapatkan komposisi perekat yang tepat dalam pembuatan pot organik. Selanjutnya perekat kanji dan gambir ditambahkan air sebanyak $150 \mathrm{ml}$, lalu dipanaskan diatas hot plate sampai mengental. Setelah perekat mengental dilakukan proses pencampuran sampai semua bahan tercampur rata.

Tabel 1. Komposisi Perekat Kanji dan Gambir

\begin{tabular}{ccccc}
\hline Perlakuan & $\begin{array}{c}\text { Fiber } \\
\text { (gr) }\end{array}$ & $\begin{array}{c}\text { Kanji } \\
\text { (gr) }\end{array}$ & $\begin{array}{c}\text { Gambir } \\
\text { (gr) }\end{array}$ & $\begin{array}{c}\text { Air } \\
\text { (m) }\end{array}$ \\
\hline P1 & 100 & 50 & 0 & 150 \\
P2 & 100 & 37,5 & 12,5 & 150 \\
P3 & 100 & 25 & 25 & 150 \\
P4 & 100 & 12,5 & 37,5 & 150 \\
P5 & 100 & 0 & 50 & 150 \\
\hline
\end{tabular}




\subsection{Pencetakan Pot Organik}

Pot dibentuk menggunakan cetakan pot plastik sampai benar-benar berbentuk padat. Selanjutnya pot yang sudah terbentuk lalu dikeluarkan dari cetakan dan dikeringkan dengan menggunakan panas matahari selama total 15 jam (2-3 hari menyesuaikan durasi cahaya matahari setiap harinya).

\subsection{Karakterisasi Pot Organik}

\subsubsection{Uji Kadar Air}

Berat awal pot organik ditimbang kemudian dioven selama 2 jam dengan suhu $105^{\circ} \mathrm{C}$ dan dimasukan dalam desikator selama 15 menit. Kemudian berat akhir pot organik ditimbang (Dani, 2016). Kadar air pot organik dihitung menggunakan rumus berikut:

$$
\% \text { Kadar Air }=\frac{\text { berat awal }(g)-\text { berat akhir }(g)}{\text { berat awal }(g)} \times 100 \%
$$

\subsubsection{Uji Daya Serap Air}

Berat awal pot $\left(\mathrm{m}_{\mathrm{a}}\right)$ ditimbang kemudian direndam dalam air (sampai tenggelam) selama 30 menit, selanjutnya ditiriskan selama 2 menit dan ditimbang masa akhir pot dan dicatat perubahan berat pot $\left(m_{b}\right)($ Dani, 2016). Perhitungan indeks daya serap air pot dihitung dengan menggunakan persamaan berikut:

$$
\% \text { Penyerapan }=\frac{m b-m a}{m a} \times 100 \%
$$

Keterangan:

$$
\begin{aligned}
& m_{b}: \text { masa akhir pot setelah diredam } 30 \text { menit }(\mathrm{Kg}) \\
& m_{a}: \text { masa awal pot sebelum direndam }(\mathrm{Kg})
\end{aligned}
$$

\subsubsection{Uji Organoleptik}

Uji organoleptik yang dilakukan adalah uji score sheet yang terdiri dari uji hedonik dan uji mutu hedonik terhadap warna dan tekstur (Setyaningsih et al., 2010). Panelis yang digunakan sebanyak 15 orang yang membidangi tanaman dan pembibitan. Uji hedonik dan uji mutu hedonik ini menggunakan 5 (lima) skala numerik seperti terlihat pada Tabel 2.

\section{HASIL DAN PEMBAHASAN}

\subsection{Pembuatan Pot Organik}

Pemotongan bahan fiber dalam pembuatan pot organik sebesar $\pm 0,5 \mathrm{~cm}$ bertujuan untuk mempermudah pencetakan pot serta untuk mempermudah proses penguraiannya di lingkungan. 
Fiber yang sudah dipotong kemudian dicampurkan dengan perekat alami yaitu tepung tapioka dan gambir, agar pot yang terbentuk cukup kuat untuk digunakan sebagai media tanam. Pot organik kemudian dicetak dan dikeringkan agar mengeras dan bisa digunakan sebagai media tanam.

Salah satu faktor penting dalam pembuatan pot organik adalah jenis dan jumlah perekat yang ditambahkan agar pot yang dihasilkan mempunyai kekerasan dan tekstur yang kokoh (tidak rusak ketika ditambahkan tanah atau media tanam) (Gambar 1). Perekat yang digunakan adalah perekat alami dari tepung tapioka dan gambir. Penggunaan bahan alami ini dimaksudkan agar pot yang dihasilkan mudah terdegradasi di lingkungan (Alshehrei, 2017; Paramita et al., 2012).

Tabel 2. Skala uji hedonik dan mutu hedonik

\begin{tabular}{lclccc}
\hline \multirow{2}{*}{ Uji Hedonik } & & \multicolumn{4}{c}{ Uji Mutu Hedonik } \\
\cline { 2 - 6 } & & \multicolumn{2}{c}{ Warna } \\
\multicolumn{1}{c}{ Skala Hedonik } & Numerik & \multicolumn{1}{c}{$\begin{array}{c}\text { Tekstur } \\
\text { Hedonik }\end{array}$} & $\begin{array}{c}\text { Skala } \\
\text { Numerik }\end{array}$ & $\begin{array}{c}\text { Skala Mutu } \\
\text { Hedonik }\end{array}$ & $\begin{array}{c}\text { Skala } \\
\text { Numerik }\end{array}$ \\
\hline Sangat suka & 5 & Cokelat kehitaman & 5 & Sangat keras & 5 \\
Suka & 4 & Cokelat tua & 4 & Keras & 4 \\
\hline Agak suka & 3 & Cokelat & 3 & Agak keras & 3 \\
Tidak Suka & 2 & Cokelat muda & 2 & Tidak Keras & 2 \\
Sangat Tidak Suka & 1 & Tidak Cokelat & 1 & Sangat tidak keras & 1 \\
\hline
\end{tabular}
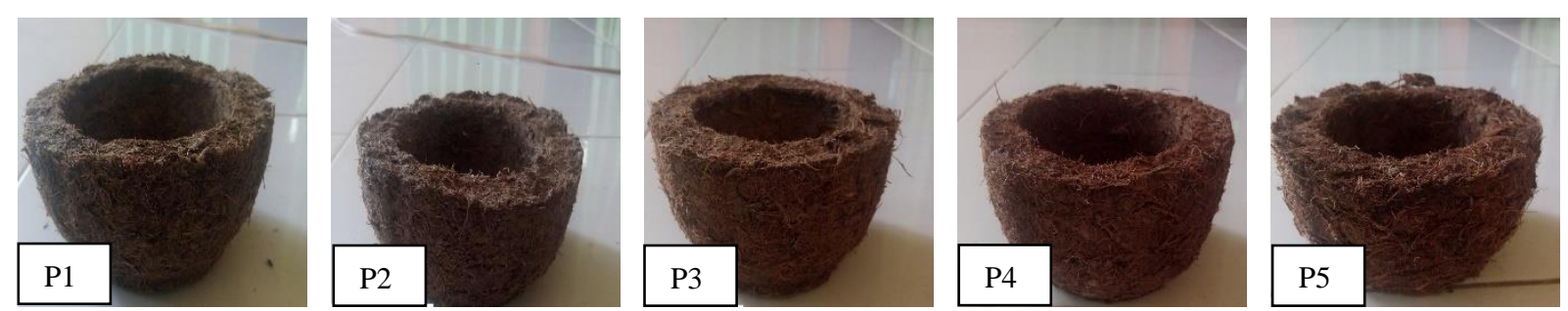

Gambar 1. Pot organik dari limbah fiber kelapa sawit

\subsection{Karakterisasi Pot Organik}

\subsubsection{Kadar Air}

Uji kadar air dilakukan dengan membandingkan berat awal pot dengan berat akhir pot yang sudah dipanaskan dalam oven selama selama 2 jam pada suhu $105^{\circ} \mathrm{C}$. Diketahui bahwa kadar air yang tertinggi terdapat pada perlakuan P1 (10,59\%) dan yang terendah terdapat pada perlakuan P2 $(10,11$ $\%)$. Kadar air semua pot organik yang diperoleh tidak berbeda signifikan, dikarenakan lama 
pengeringan yang dilakukan seragam selama 15 jam atau 2-3 hari pengeringan dibawah sinar matahari. Rata-rata nilai kadar air pot organik adalah 10,24\% (Gambar 2).

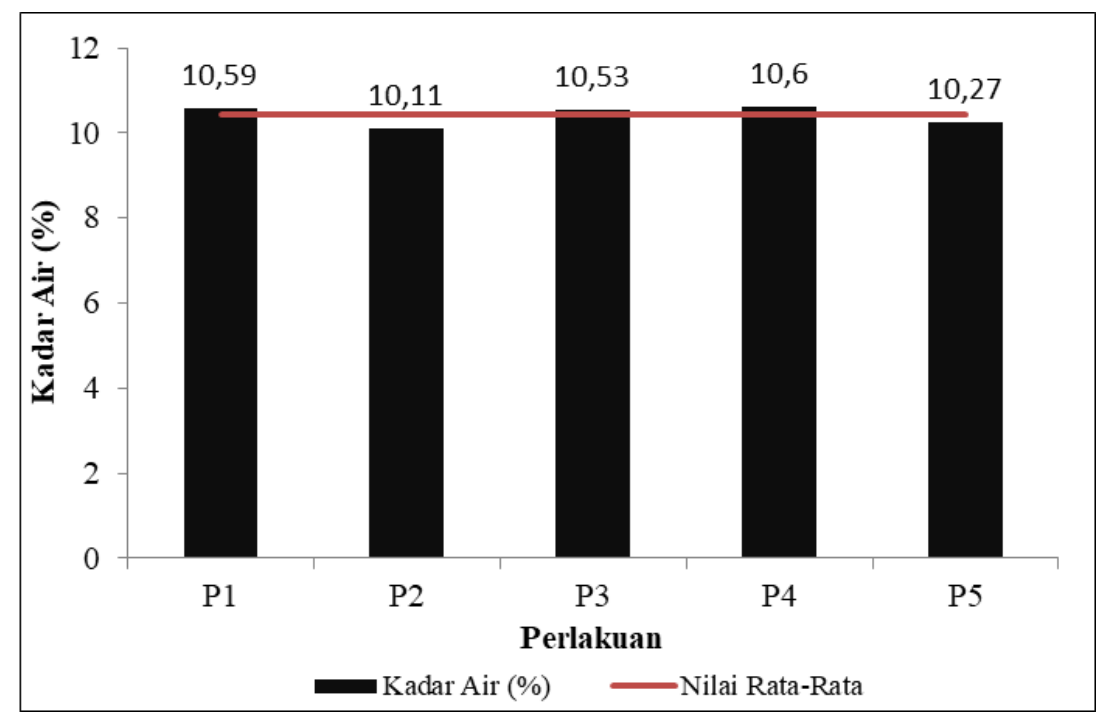

Gambar 2. Hasil Uji Kadar Air Pot Organik

Kadar air merupakan faktor yang sangat berpengaruh terhadap penurunan mutu pot organik, karena dapat merusak tekstur pot dan mengundang tumbuhnya jamur pengganggu. Semakin rendah kadar air maka akan memperpanjang masa simpan pot organik tersebut sedangkan semakin tinggi kadar air pot organik umumnya menyebabkan pot mudah rusak, baik karena kerusakan mikrobiologis maupun reaksi kimia (Herawati, 2008; Murdhiani \& Rosmaiti, 2017). Selain itu, kadar air juga berpengaruh dalam mempercepat terjadinya perubahan dan penguraian bahan-bahan organik pada media tanam maupun pot organik (Widarti et al., 2015)

\subsubsection{Daya Serap Air}

Daya serap air diperoleh dengan membandingkan berat sebelum dan sesudah pot direndam di dalam air. Uji daya air perlu dilakukan untuk mengetahui tingkat ketahanan pot ketika diaplikasikan di lapangan. Hasil uji daya serap air tertinggi terdapat pada P5 $(155,48 \%)$ dan terendah terdapat pada P2 (129,25\%). Secara lengkap hasil uji daya serap air dapat dilihat pada Gambar 3. Dayap serap air terendah diperoleh dari P1 dan P2, hal ini mengindikasikan bahwa semakin besar komposisi kanji, maka daya serap air semakin rendah. Hal ini dikarenakan perekat kanji mempermudah penutupan rongga kapiler, sehingga air tidak mudah terserap oleh pot organik (Roza, 2009). 


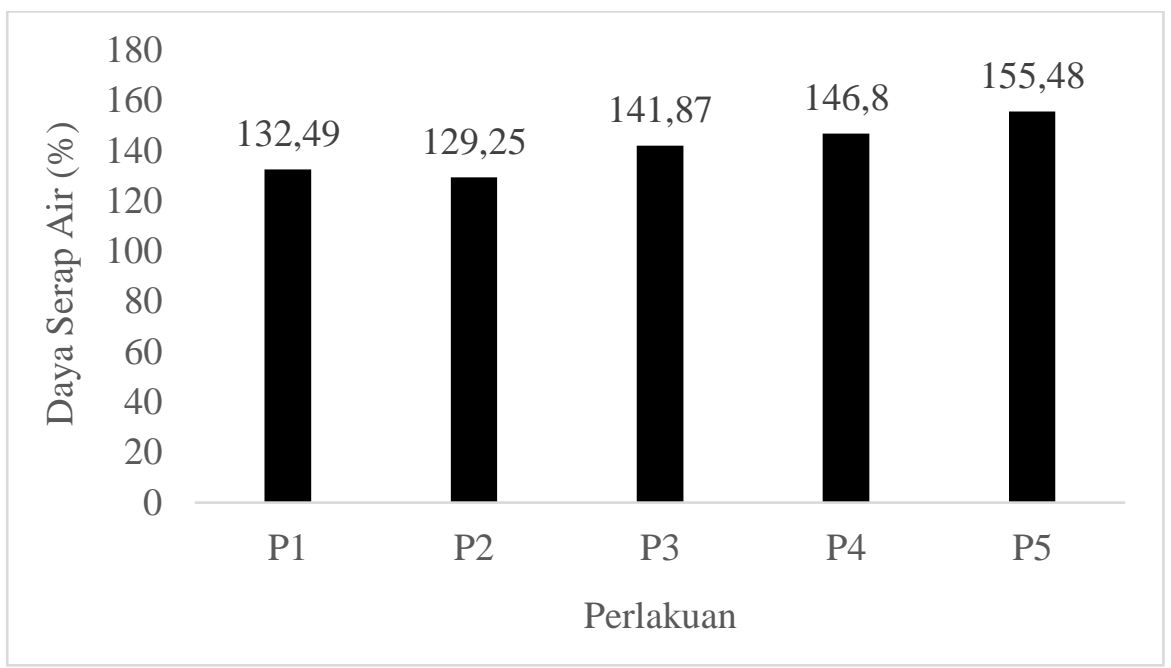

Gambar 3. Hasil Uji Daya Serap Air Pot Organik

Pot organik merupakan suatu bahan yang memiliki sifat menyerap air dan uap. Sebaliknya, apabila udara disekitar pot organik menjadi kering, pot organik akan kehilangan air sampai kembali mencapai keseimbangan. Faktor-faktor yang mempengaruhi tinggi rendahnya penyerapan air pot organik adalah adanya saluran kapiler yang menghubungkan antara ruang kosong, volume ruang kosong diantar pot, luas permukaan pot yang tidak ditutupi perekat (Roza, 2009).

Tingginya daya serap air pot organik terdapat pada P5 yang menggunakan 100\% perekat gambir terjadi karena ketahanan perekat gambir terhadap air yang kurang baik. Pot organik yang daya serap airnya tinggi memiliki ketahanan yang rendah, sedangkan pot organik yang daya serap airnya rendah memiliki ketahanan yang cukup baik, sehingga dapat diaplikasikan diluar maupun di dalam ruangan.

\subsection{Uji Organoleptik (Uji Hedonik dan Uji Mutu Hedonik)}

Berdasarkan hasil uji hedonik warna pot organik dari serabut (fiber) kelapa sawit tingkat kesukaan tertinggi diperoleh pada pot dengan perlakuan menggunakan perbandingan gambir 50 gram : kanji 0 gram (P5) sebesar 3,76. Warna dominan pot organik pada P5 dipengaruhi oleh penambahan gambir yang tidak hanya berfungsi sebagai perekat tapi juga berfungsi sebagai zat pewarna (Kasim, 2011). Berdasarkan uji hedonik tekstur pot organik diketahui bahwa perlakuan P1 menggunakan perbandingan kanji 50 gram : gambir 0 gram mendapatkan nilai tingkat kesukaan tertinggi yaitu 3,91. Tekstur pot menjadi lebih padat dan menarik disebabkan karena tepung tapioka memiliki kandungan amilopektin yang tinggi, sehingga mempunyai sifat mudah menggumpal, mempunyai daya lekat yang tinggi, tidak mudah pecah atau rusak dengan suhu gelatinisasi relatif rendah (52-64 
$\left.{ }^{\circ} \mathrm{C}\right)$ (Haryanti, et al., 2014). Secara lengkap nilai uji hedonik rata-rata dari tiga ulangan pot yang dihasilkan dapat dilihat pada Tabel 3 dan Gambar 4.

Tabel 3. Hasil Uji Hedonik Pot Organik

\begin{tabular}{cccccc}
\hline Parameter & P1 & P2 & P3 & P4 & P5 \\
\hline Tekstur & 3,91 & 3,78 & 3,58 & 3,53 & 3,51 \\
Warna & 3,69 & 3,67 & 3,44 & 3,69 & 3,76 \\
\hline
\end{tabular}

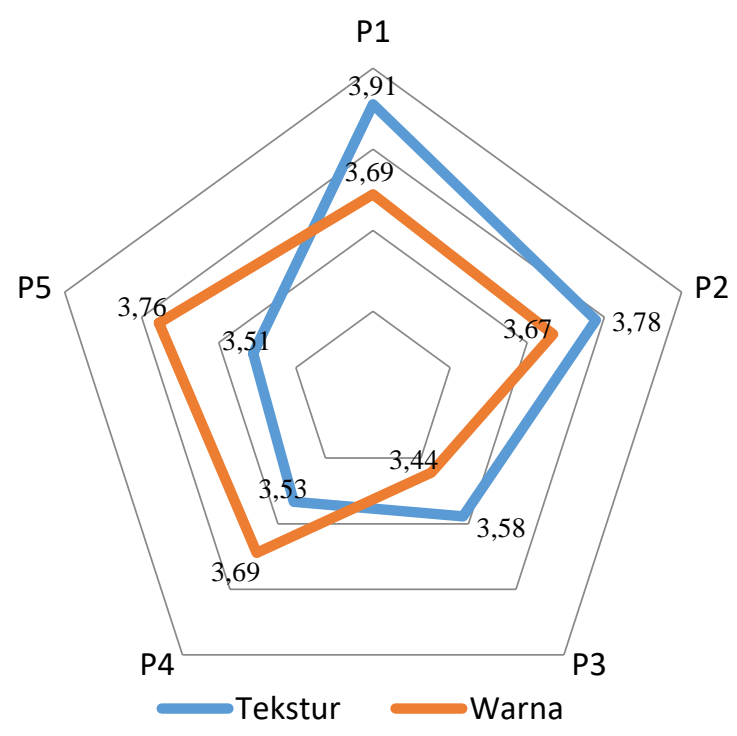

Gambar 4. Spiderweb chart uji hedonik tekstur dan warna pot organik

Berdasarkan hasil uji mutu hedonik pot organik dari serabut (fiber) kelapa sawit penilaian tertinggi warna pot organik terdapat pada P1 yaitu "Cokelat Tua", disebabkan serabut (fiber) kelapa sawit memiliki warna khas cokelat dan mengandung protein kasar sekitar 4\% dan serat kasar 36\% (lignin 26\%) serta mempunyai kalor 2637kkal/kg-3998kkal/kg (Kamal, 2014). Berdasarkan analisis Anova yang dilakukan diketahui bahwa nilai $\mathrm{F}$ hitung lebih kecil dari $\mathrm{F}$ tabel 5\%, sehingga disimpulkan bahwa perlakuan tidak berpengaruh sangat nyata terhadap warna pot organik (Tabel 4).

Uji mutu hedonik tekstur pot organik bahwa nilai tertinggi diperoleh oleh pot dengan perlakuan P1 yaitu "Keras". Tekstur keras pot organik disebabkan karena tepung tapioka yang digunakan sebagai perekat mengandung amilopektin yang tinggi, sehingga mempunyai sifat mudah menggumpal, mempunyai daya lekat yang tinggi, tidak mudah pecah atau rusak dan suhu gelatinisasinya relatif rendah $\left(52-64{ }^{\circ} \mathrm{C}\right)$ (Saraswati, 2009). Berdasarkan analisis Anova diketahui bahwa nilai yang $\mathrm{F}$ hitung lebih besar dari $\mathrm{F}$ tabel $5 \%$ yang artinya perlakuan berpengaruh nyata terhadap tekstur pot organik (Tabel 5). Berdasarkan hasil tersebut dilakukan uji lanjut dengan uji Duncan's Multiple 
Range Test (DMRT) untuk mengetahui pengaruh tiap perlakuan. Hasil uji Duncan's Multiple Range Test (DMRT ) menunjukkan bahwa P1 berbeda nyata dengan $\mathrm{P} 2, \mathrm{P} 3, \mathrm{P} 4$, dan $\mathrm{P} 5$. P2 berbeda nyata dengan P1, P4, P5. P3 berbeda nyata dengan P1. P4 berbeda nyata dengan P1 dan P2. P5 berbeda nyata dengan P1 dan P2. Berdasarkan uji DMRT (Tabel 6) tekstur terbaik pada perlakuan P1 (perekat kanji $100 \%$ ) dengan nilai rat-rata 4.

Tabel 4. Uji Anova mutu hedonik warna pot organik

\begin{tabular}{|c|c|c|c|c|c|}
\hline $\begin{array}{c}\text { Sumber } \\
\text { Varian/Ragam } \\
\end{array}$ & $\begin{array}{c}\text { SS/Jumlah } \\
\text { Kuadrat }\end{array}$ & $\begin{array}{c}\text { df/Kuadrat } \\
\text { Bebas }\end{array}$ & $\begin{array}{c}\text { MS/Kuadrat } \\
\text { Tengah } \\
\end{array}$ & $F$ Hitung & F Tabel 5\% \\
\hline Perlakuan & 1,026963 & 4 & 0,256741 & 1,196823 & 3,47805 \\
\hline Galat & 2,145185 & 10 & 0,214519 & & \\
\hline Total & 3,172148 & 14 & & & \\
\hline
\end{tabular}

Keterangan: Tidak Berpengaruh Nyata ( F hitung < F tabel 5\%)

Tabel 5. Uji Anova mutu hedonik tekstur pot organik

\begin{tabular}{lcrrrr}
\hline \multicolumn{1}{c}{$\begin{array}{c}\text { Sumber } \\
\text { Varian/Ragam }\end{array}$} & $\begin{array}{c}\text { SS/Jumlah } \\
\text { Kuadrat }\end{array}$ & $\begin{array}{c}\text { Dff/Kuadrat } \\
\text { Bebas }\end{array}$ & $\begin{array}{c}\text { MS/Kuadrat } \\
\text { Tengah }\end{array}$ & F Hitung & F Tabel 5\% \\
\hline Perlakuan & 0,558815 & 4 & 0,139704 & $9,822917^{* *}$ & 3,47805 \\
Galat & 0,142222 & 10 & 0,014222 & \\
& & & & \\
Total & 0,701037 & 14 & & \\
\hline & & &
\end{tabular}

Tabel 6. Uji DMRT tekstur pot organik

\begin{tabular}{ccc} 
& \multicolumn{2}{c}{ Tabel 6. Uji DMRT tekstur pot organik } \\
\cline { 2 - 3 } & Perlakuan & Rata-rata Tekstur (0,05 \%) \\
\hline P5 & $3,44^{\mathrm{a}}$ \\
P4 & $3,55^{\mathrm{a}}$ \\
P3 & $3,71^{\mathrm{ac}}$ \\
$\mathrm{P} 2$ & $3,8 \mathrm{~b}^{\mathrm{cd}}$ \\
$\mathrm{P} 1$ & $4^{\mathrm{e}}$ \\
\cline { 2 - 2 } Keterangan: angka yang diikuti huruf sama tidak berbeda nyata $(\alpha=5 \%)$
\end{tabular}

\section{KESIMPULAN}

Pot organik berbahan baku limbah serabut (fiber) kelapa sawit selain dapat mengurangi potensi limbah sawit juga dapat meningkatkan nilai ekonomi limbah. Pada penelitian ini dilakukan optimasi komposisi penambahan perekat alami pada pembuatan pot organik berbahan baku limbah serabut (fiber) kelapa sawit, serta melakukan mengkarakterisasi fisik dan tingkat kesukaan terhadap pot organik. Hasil penelitian menunjukkan, kadar air pot organik berkisar antara 10,11-10,59\%. Sedangkan daya serap air pot organik berkisar antara 129,25-155,48\%. Pot dengan kadar air dan 
daya serap air paling rendah diperoleh dari perlakuan P2. Uji hedonik pot organik menunjukkan bahwa tingkat penerimaan pot tertinggi dari segi warna adalah pot dari perlakuan P5 dan segi tekstur adalah pot dari perlakuan P1.

\section{UCAPAN TERIMA KASIH}

Terimakasih disampaikan kepada Politeknik Negeri Tanah Laut yang telah memberikan fasilitas dan dukungan dalam pelaksanaan penelitian ini.

\section{DAFTAR PUSTAKA}

Alshehrei, F., (2017), Biodegradation of synthetic and natural plastic by microorganisms, Journal of Applied \& Environmental Microbiology, 5(1), 8-19.

Dani, A. L., (2016), Pengaruh Perbedaan Konsentrasi Perekat Gambir (Uncaria gambir, Roxb) Terhadap Sifat Fisis dan Mekanis Papan Partikel Dari Sabut Buah Pinang. Fakultas Teknologi Pertanian. Universitas Andalas Padang

Haryanti, P., Setyawati, R., \& Wicaksono, R., (2014), Pengaruh Suhu dan Lama Pemanasan Suspensi Pati serta Konsentrasi Butanol terhadap Karakteristik Fisikokimia Pati Tinggi Amilosa dari Tapioka, Agritech, 34(3), 308-315.

Herawati, H., (2008), Penentuan umur simpan pada produk pangan, Jurnal Litbang Pertanian, 27(1974).

Kamal, N., (2014), Karakterisasi dan Potensi Pemanfaatan Limbah Sawit, ITENAS, Bandung.

Kamsiati, E., Herawati, H., \& Purwani, E. Y., (2017), Potensi Pengembangan Plastik Biodegradable Berbasis Pati Sagu Dan Ubikayu Di Indonesia, Jurnal Penelitian dan Pengembangan Pertanian, 36(2), 67-76.

Kasim , A., (2011), Proses Produksi dan Industri Hilir Gambir, Andalas University Press. Padang.

Kasim, A., Yumarni, Y., \& Fuadi, A., (2018), Pengaruh Suhu dan Lama Pengempaan pada Pembuatan Papan Partikel dari Batang Kelapa Sawit (Elaeis guineensis Jacq.) dengan Perekat Gambir (Uncaria gambir Roxb.) terhadap Sifat Papan, Jurnal Ilmu dan Teknologi Kayu Tropis, 5(1), 17-21.

Murdhiani \& Rosmaiti, (2017), Pembuatan Polybag Organik sebagai Tempat Media Pembibitan dari Ampas Tebu (Saccharum officinarum). Seminar N.M.I. doi.org/10.31227/osf.io/jkuy7.

Nursyamsi, N., (2015), Biopot Sebagai Pot Media Semai Pengganti Polybag yang Ramah Lingkungan, Buletin Eboni, 12(2), 121-129.

Paramita, P., Shovitri, M., \& Kuswytasari, N. D. (2012). Biodegradasi Limbah Organik Pasar dengan Menggunakan Mikroorganisme Alami Tangki Septik. Jurnal Sains dan Seni ITS, 1(1), E23-E26. 
Roza, I., (2009), Pengaruh Perbedaan Proses Penyediaan Serat dengan Cara Mekanis Limbah Tandan Kosong Sawit terhadap Papan Serat, Sainstek, 12(1), 9-17.

Saraswati, (2009), Pembuatan Filet Ikan. Kumpulan Hasil-hasil Penelitian Pasca Panen Perikanan, Pusat Penelitian Perikanan, Jakarta.

Setyaningsih, D., Apriyantono, A., \& Sari, M. P., (2010), Analisis sensori untuk industri pangan dan agro, Institut Pertanian Bogor Press, Bogor.

Susilawati \& Supijatno, (2015), Pengelolaan Limbah Kelapa Sawit (Elaeis guineensis Jacq.) di Perkebunan Kelapa Sawit, Riau, Bul. Agrohorti., 3(2), 203-212.

Verma, R., Vinoda, K. S., Papireddy, M., \& Gowda, A. N. S., (2016), Toxic Pollutants from Plastic Waste- A Review, Procedia Environmental Sciences, 35, 701-708. https://doi.org/10.1016/j.proenv.2016.07.069.

Widarti, B. N., Wardhini, W. K., \& Sarwono, E., (2015), Pengaruh rasio C/N bahan baku pada pembuatan kompos dari kubis dan kulit pisang, Jurnal Integrasi Proses, 5(2). 